\title{
Heuristic Teaching Method on Innovative Talents Cultivation of Electrical Engineering
}

\author{
Sun Huiqin Sun Kejun Liu Qingrui \\ Hebei University of Science and Technology \\ Shijiazhuang, China \\ e-mail: shqczx@hebust.edu.cn
}

\begin{abstract}
The innovative talents training is an important part of the innovation system in higher education. Electrical engineering experimental class talent cultivation is a useful exploration on the innovation education to improve the education quality of teaching for outstanding students by the comprehensive reforms on the talent training mode, curriculum system, teaching content, teaching method and evaluation system. Heuristic teaching is beneficial to the students in experimental class to cultivate students' creative thinking and creative ability. This paper analyzes the necessity and advantages for heuristic method. It also expatiates on the organization and approaches of the method in class teaching and graduation design for electrical engineering.
\end{abstract}

Keywords-heuristic teaching; innovative talents training; experimental class; class teaching; graduation design

\section{INTRODUCTION}

The innovative talents training is an exploration to cultivate high quality talents and creative talents with good moral character, knowledge and ability based on the accumulation experience. This is a comprehensive reform plan involving talent training mode, curriculum system, teaching content, teaching method and evaluation system [1]. The universities have launched experimental class to reform the training mode and train innovative talents.

Experimental class talents cultivation is useful exploration on classified cultivation and innovation education teaching reform for outstanding students under the background of popularization in higher education [2]. It aims to train a group of performance outstanding research and applied talents with quality education teaching resources, better learning environment and innovate training pattern by setting electrical engineering experimental class. Experimental class talent training reforms the teaching content and teaching method actively based on the principle of the people-oriented and individualized. It cultivates the creative engineering and technical talents with strong foundation and broad scope.

Heuristic education is an education idea regression on the educatee-oriented. It corresponds with the inherent requirement of teaching ideas. Heuristic is a term which describes a range of techniques which enable the teacher to get learners to provide information rather than giving it to them. Commonly, heuristic is used to ask learners to come up with vocabulary and language forms and rules, and to brainstorm a topic at the start of a skills lesson [3]. Heuristic teaching is beneficial to the students in experimental class to cultivate students' creative thinking and creative ability.

\section{HEURISTIC TEACHING METHOD}

Teaching is a form of interpersonal communication between two people - a teacher and a learner. The teaching-learning process is a human transaction involving the teacher, learner and learning group in a set of dynamic interrelationships. Teaching is a human relational problem [4]. As a relational problem, four factors are essential in the successful teaching and learning [5]. There are the role of the teacher and the knowledge, attitudes and skills that the teacher brings to the relationship, the role of the learners and the experiences and knowledge that the learners bring to the relationship, and the conditions or external influences which enhance the teaching-learning process and the types of interactions which occur between teacher and learner.

A. Necessity of heuristic teaching method

Heuristic teaching is an advanced and scientific teaching method. It is not only in conformity with the guiding ideology of students' learning law, but also is an effective means on comprehensive training students' innovative thinking ability.

Heuristic teaching establishes the students' dominant position and the teachers' leading role. The essence of heuristic teaching is to let students involved actively in the learning activities, give full play to the subjective initiative, arouse students' positive thinking, the initiative to explore the answer to the question, give full play to the students' learning enthusiasm.

Electrical engineering has given a profound impact on our daily lives. It is an exciting and dynamic field. Heuristic teaching method is put forward in education to meet society's demands in training talents' knowledge, skill, quality etc. Heuristic teaching method is suitable for the students' properties of electrical engineering experimental class. Elicitation can help them learn how to work things out for themselves. It also can help them fell into the habit of thinking by themselves and in a creative way.

B. Requirements of students

A perfective effect is that students are responding to almost everything you say in almost every stage of the lesson. Sometimes heuristic can be met by silence. This could mean that students don't know the answer, that they do know the answer but aren't confident, that they would know the answer but haven't understood your elicitation and so on. So it needs a higher demand to students to get a perfective effect by the heuristic teaching method. Students should do pre-learning task carefully and take every 
opportunity to express in class.

The students in electrical engineering experimental class have good learning abilities and strong foundation. They have the ability of practice and the spirit of creativity. They like thinking and doing experiment. They want to do something new. They are suitable for the heuristic teaching method.

\section{Requirements of teachers}

Teachers play a key role in the whole teaching and learning system. The leading role of teachers use the appropriate methods to help students in active learning based on teaching goal. They not only teach students knowledge based on textbooks, but also control all the elements in class. Modern teachers have to perform many tasks at the same time such as controller, assessor, organizer, prompter, participant, resource, tutor, observer, performer and teaching aid. From this viewpoint, it is understood that the teacher must be ultimately well-controlled throughout the lesson as she/he is required to play many roles at the same time [6]. To gain an acceptable outcome of the heuristic teaching method, four steps must be considered in organization. There are textbooks or references choice, pre-learning task before class, interaction during class and assignment after class.

\section{HEURISTIC TEACHING IN CLASS TEACHING OF ELECTRICAL ENGINEERING}

\section{A. Restructuring and optimizing the teaching content}

Heuristic teaching should lay stress on the characteristics of specialty courses which are the basic, the comprehensive and the practical. During the class it should pay more attention on the essence and the new. It should distinguish primary and secondary, highlight key points, and focus on the core content. It also should analyze the difficult problems deeply avoiding making a clean breast of teaching material contents. At the same time, the teaching contents should update content constantly to reflect the trend of the development of modern science and technology. It help students to explore new knowledge information and learn to anticipate future development and change things and ideas so as to stimulate and cultivate students' autonomous learning motivation and cultivate students' creative thinking ability, and further to cultivate and stimulate the students' ability of independent innovation.

\section{B. Changing of teaching mode}

The new teaching methodologies to increase interactivity should be explored such as the trial and error method, brainstorming, analog innovation and information pairing.

Teachers should organize the class discussion, questioning, lectures and other activities to make the students participate in teaching activities actively. The group is more important than the individual in the class. Assigning in-class teams can be beneficial by promoting and guaranteeing student interaction. Teachers can initiate a feedback session about the lesson which teachers can check how they coped with the exercise [7]. During the class, students should be the dominant role in the teaching activities and teachers' teaching and students' thinking must be synchronous by giving problem and discussing freely. Keeping the students' enthusiasms and interests of studying is very important, for it will benefit the teaching and studying for both teachers and students.

\section{Reforming the teaching evaluation system}

The teachers and the students' individuality differ in thousands ways. In the traditional mode, scores are the only standard to evaluate the students and teachers. This gives the examination education a broad market. So setting up scientific evaluation system can provide plenty of power for the heuristic teaching. The new evaluation system should consider the principle of the objectivity, development, guidance and planning. It can use variety testing methods and open questions to evaluate of student's learning effect and related ability objectively. It is against education innovation and cultivating talents with creative thinking by making more and finer teaching evaluation standard. For teaching evaluation and requirements should be fully considered the characteristics of talent training, mobilize the enthusiasm of the teachers' innovation. It does not require the monotony, leave room for innovation.

\section{HEURISTIC TEACHING IN GRADUATION DESIGN OF ELECTRICAL ENGINEERING}

Higher education should attach importance to cultivate college students' practice ability, innovation ability and scientific spirit. Undergraduate graduation design is the important teaching link to realize the goal of cultivating, which is the important practice to cultivate students' innovation ability, practice ability and scientific spirit.

There are several problems during the process of the graduation design. Colleges have not pay attention on the innovative approaches. There is little discussion on the discipline of the scientific method from the point of view of epistemology and methodology, which restricts students' thesis research in innovation ability. Innovation should solve the thinking obstacles during thinking process. The thinking obstacles are from psychological inertia and limited knowledge. So during the design, it is difficult to choose a topic and can't find innovations. Many colleges' undergraduate design does not require opening report. Even if there is opening report requirements, the study scheme and technical route are often simplified as the research steps. It lacks deep thinking on the validity of the research methods and the innovation of idea. This phenomenon has seriously affected the quality of the design.

Putting the heuristic teaching method through selection topics, guidance and assessment can improve the teachers' guidance ability and students' enthusiasm.

\section{A. Optimization selection topics}

If you want to optimize the topics, teachers must grasp the students' academic performance and learning ability, students' practical ability and interests, and work direction accurately. According to each students' different features teachers draw up different graduation design topics. Theory research topics should be prepared for the students who want to study on graduate school. It should arrange topics 
according to students' employment unit for the students who want to get a job. Topics should conform to the students' actual level with moderate difficulty. It should improve the challenging for higher ability students. When selecting topic, it advocate "student-centered" two-way choice between teachers and students to mobilize students' enthusiasm.

\section{B. Change the guidance mode}

Changing the traditional single cramming guidance mode and using varied guidance mode to mobilize students' subjective initiative.

It must strengthen the inspiration of subject. It should select the key problems to solve and describe the problem clearly. The clear is the description; the easier it is to solve the problem [8]. It analyzes the problem by comparative classification. Though the idea differentiation, students can find the accurate way to solve the problem. New thoughts lead to new solutions, so the students become active participants in their own learning process together with their teacher guides and their co-learners. It is beneficial to improve the innovation through the scientific method in research.

According to the research topic, the students are divided into different groups for discussion system. Group supervises each other and report regularly to summarize the former period of work. The students have better supervise role and can improve students' comprehensive ability.

\section{Adjusting assessment mode}

Graduate design assessment mode has a great adjustment. It encourages students to do experiments, make products and write software. It also encourages students to participate in extracurricular scientific research activities, such as the challenge cup, college students' electronic design competition, the rewards can be included in the graduation design results. In addition, if students published professional papers in journals, it also can be included in the graduation design results.

\section{V.CONCLUSION}

Comparing to the traditional teaching, the heuristic teaching method is effective and suitable for electrical engineering experimental class students. It can improve students' ability on analysis and solution problems and cultivate the creative engineering and technical talents. Of course the method is not perfect since it has a few shortcomings, such as the less information during the teaching process in the class. It needs a higher demand both to teachers and to students to get a perfective effect. These disadvantages can be improved with the further development of the innovative talents training.

\section{REFERENCES}

[1] Zhou Guangli, “Grasp the opportunity to explore new ways of training talent”, China Higher Education, pp.28-30,Jan. 2011.

[2] Xu Xiaodong, “devote to talents cultivate innovative experimental plot construction”, China Higher Education,pp.9-11,Z3. 2008.

[3] Kai Zhang, "Qualities of Chinese International Journalism Professionals and the Training Model”, International Journalism and Intercultural Communication, Beijing: Beijing Broadcasting Institute Press, 2003, pp. 58.

[4] F.C. Berry, P.S. DiPiazza and S.L. Sauer, "The future of electrical and computer engineering education”, IEEE Transaction Education, Vol.46, pp. 467-476, Nov. 2003.

[5] P. Ajideh, "Schema theory-based pre-reading task: a neglected essential in the reading class", The Reading Matrix.Vol.3, No.1, pp. 1-14, Apr. 2003

[6] M. Ebner and A. Holzinger, "Successful implementation of user-centered game based learning in higher education: An example from civil engineering”, Computers \& Education, Vol.49, No.3, pp. 873-890, Nov. 2007

[7] J. Pol, "The nature, reception, and use of online peer feedback in higher education", Computers \& Education, Vol. 51, No.4, pp. 1804-1817, Dec. 2008

[8] Chen Yuan, "Exploring Innovation Education in Undergraduate Dissertations from the View of Triz Theory”, Journal of Guangdong University of Technology (Social Sciences Edition),Vol.8, pp175-176, Jul. 2008 